\title{
Improved Methodology of Accounting and Audit of Payments to Employees in Ukraine
}

\author{
Halyna Kuzmenko ${ }^{1, *}$, Kateryna Yahelska ${ }^{2}$, Oksana Artyukh$^{3}$, Iryna Babich ${ }^{4}$, Nataliia Volenshchuk ${ }^{5}$, \\ Larisa Sulimenko ${ }^{6}$

\begin{abstract}
${ }^{1}$ Institute of Economic Development Studies, Kyiv National Economic University named after Vadym Hetman, Kyiv, Ukraine
${ }^{2}$ Department of Economics, Accounting and Taxation, Donetsk National Technical University, Pokrovsk, Ukraine

${ }^{3}$ Department of Accounting and Auditing, Odessa National University of Economics, Odesa, Ukraine

${ }^{4}$ Department of Accounting and Auditing, Lutsk National Technical University, Lutsk, Ukraine

${ }^{5}$ Donetsk State Agricultural Science Station of NAASU, Pokrovsk, Ukraine

${ }^{6}$ Department of Accounting, Taxation and Audit, Polissia National University, Zhytomyr, Ukraine
\end{abstract}

Received November 28, 2020; Revised January 6, 2021; Accepted January 28, 2021

\section{Cite This Paper in the following Citation Styles}

(a): [1] Halyna Kuzmenko, Kateryna Yahelska, Oksana Artyukh, Iryna Babich, Nataliia Volenshchuk, Larisa Sulimenko, "Improved Methodology of Accounting and Audit of Payments to Employees in Ukraine," Universal Journal of Accounting and Finance, Vol. 9, No. 1, pp. 44 - 53, 2021. DOI: 10.13189/ujaf.2021.090105.

(b): Halyna Kuzmenko, Kateryna Yahelska, Oksana Artyukh, Iryna Babich, Nataliia Volenshchuk, Larisa Sulimenko (2021). Improved Methodology of Accounting and Audit of Payments to Employees in Ukraine. Universal Journal of Accounting and Finance, 9(1), 44 - 53. DOI: 10.13189/ujaf.2021.090105.

Copyright@2021 by authors, all rights reserved. Authors agree that this article remains permanently open access under the terms of the Creative Commons Attribution License 4.0 International License

\begin{abstract}
The issue of organization of payments to employees at the enterprise is the basis of social and labour relations of employees, employers and the state, affecting the effectiveness of labour management in general, they are one of the most critical and complex areas of work, occupying a central place in the accounting system. The authors analyzed the theoretical and methodological basis of payments to employees, compared to international and domestic standards for employee benefits. Authors also analyzed the dynamics of average and minimum wages over the past 10 years, and revealed the features of the organization of wages and the general scheme of accounting for wages. The authors demonstrated the essence of the concept of "payments to employees" and its components, analyzed in detail the features of the existing practice of accounting and audit of settlements with employees. A thorough theoretical and methodological analysis of the study allowed the authors to propose improvements in accounting for settlements with employees on practical examples, namely the detailed structure of account 66 "Payments to employees". The authors also proposed an improved audit methodology that will allow the auditor to cover all aspects of payroll accounting, investigate the correctness, timeliness, legality of reflection in payroll, cover all
\end{abstract}

aspects of payroll accounting, identify violations promptly, conduct a quality audit.

Keywords Accounting, Audit, Employee, Payment, Salary

\section{Introduction}

Theoretical and practical aspects of settlements with employees are relevant; it is one of the most challenging economic categories. Accounting for payments to employees is one of the most critical and complex work areas, occupying one of the central places in the entire accounting system [1-3]. For employees to receive wages and other benefits, it is crucial to promptly make the necessary calculations and draw up documents correctly [4-6]. Besides, wages are one of the factors of efficiency of the enterprise, as the amount of accrued wages, timeliness and completeness of payments to employees affect the quality of work of employees and the number of costs of the enterprise. Besides, wages are the basis for calculating a single social contribution and withholding personal income tax [7-8]. Accounting for labour and 
benefits is one of the most important and complicated in the enterprise's entire accounting system. In any company, this section of accounting is mandatory; it is complicated and time-consuming. That is why the problematic issues of accounting for settlements with employees need in-depth research, as their solution, in turn, will have a positive impact on the formation of reliable information on the calculations of wages of employees, both tax and statistical accounting in general. Besides, the constant changes in the legal and organizational framework of accounting require the modern accountant to make timely adjustments both in accounting and when displaying information about wages in the enterprise's reporting [9-11]. Due to constant changes in legislation, when conducting inspections of wages, there are often deviations of accounting data from these inspections; there is also no audit methodology for checking settlements with employees at the enterprise.

\section{Theoretical and Methodological Issues of Accounting and Audit of Payments to Employees}

\subsection{Theoretical Issues of Accounting Payments to Employees}

Payments to employees represent a significant share of the company's costs, so the correctness and reliability of the reflection in the accounting of information on wages significantly impact the financial result of economic activity. In today's society, the issue of settlements with employees of the enterprise is increasingly attracting practitioners' attention. It is vital in the reproduction of the social product, one of the main factors in ensuring the efficiency of the economy, and the main component of employee benefits.

By International Accounting Standard (IAS) 19, employee benefits, employee benefits are all forms of compensation provided by an entity in exchange for employees' services [12]. As for the employee's services, he may provide them full-time or part-time, based on permanent, periodic or temporary employment.
Methodological principles of formation in the accounting of information on payments (in monetary and non-monetary forms) for work performed by employees, and its disclosure in the financial statements is determined by Regulation (Standard) of Accounting 26 "Payments to employees", which came into force on January 1. 2004 [13]. Employee benefits include benefits provided to either employees or their dependents and may take the form of cash benefits (or goods and services) directly to employees, their wives, husbands, children or other dependents or others, such as insurance companies.

We compare IAS 19 and ARS 26 on the classification of employee benefits (Fig. 1).

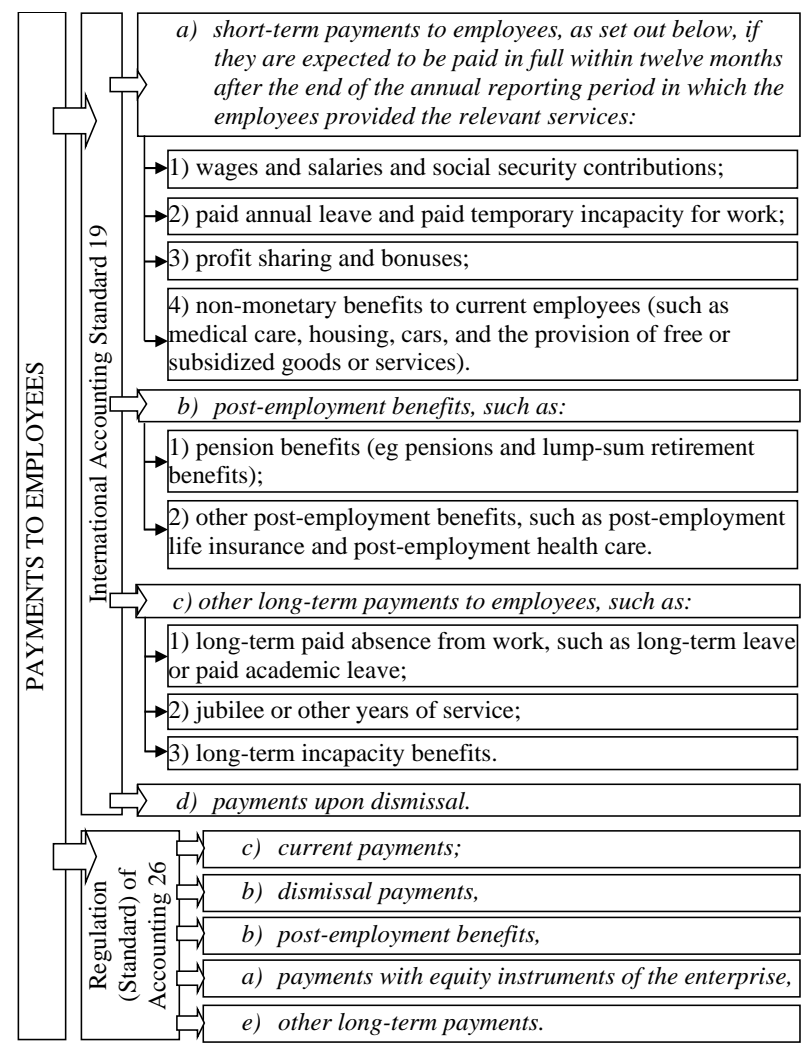

Figure 1. Classification to employees with workers according to IAS 19 and ARS 26

As a rule, wages account for more than $60 \%$ of all payments to employees [14], so let's analyze this category's dynamics (Fig. 2). 


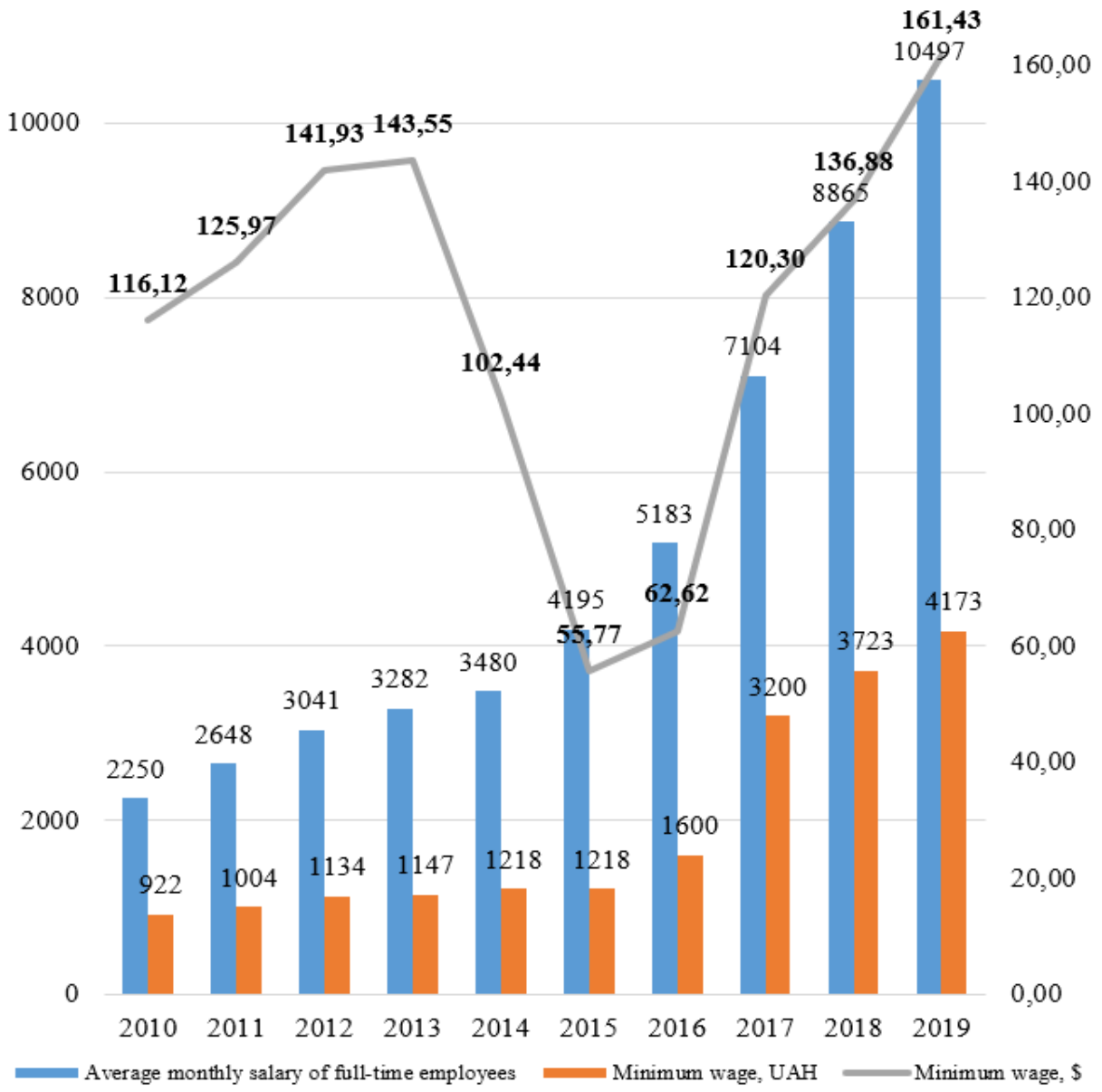

Figure 2. Dynamics of average and minimum wages

According to Fig. 2, the largest declines in minimum wages in dollar terms occurred in 2014 (-28.6\%) and 2015 (-45.6\%). Since 2016, there has been a gradual, and since 2017 a record (by 92.1\%) increase in the minimum wage and it amounted to UAH 3,200. The average salary is also growing, from 2016 to 2019 it grew by about 25\% annually.

The main document that determines the order of organization of wages at the enterprise, the size of the basic and additional wages, the order of bonuses for employees, is the Regulations on wages at the enterprise.

This document should contain information about:

- general principles of organization of remuneration at the enterprise, systems and forms of remuneration applicable to different categories of employees;

- staffing of employees of the enterprise;

- construction of the basic (tariff) payment with instructions on positions and professions of tariff rates and salaries or the order of calculation, depending on indicators of work of the worker and the enterprise as a whole;

- stipulated surcharges, allowances and compensations with the indication of their sizes; other bonus systems used at the enterprise and the bonus scale.

Current regulations carry out the organization of remuneration in Ukraine; general agreement at the state level; sectoral and regional agreements; collective agreements; employment contracts; other enterprises' internal regulations (Fig. 3).

Wages consist of basic, additional wages and other incentive and compensation payments. According to the Law of Ukraine "On Remuneration of Labour", the basic salary is the remuneration for the work performed following the established labour standards (time norms, production, maintenance, job responsibilities). It is set in the form of tariff rates (salaries) and piece rates for workers and salaries for employees.

Additional salary is a reward for work above the established norms, labour successes and ingenuity, and special working conditions. The additional salary fund includes surcharges, allowances, guarantees and compensatory payments provided by the current legislation, the bonuses connected with the performance of production tasks and functions. 


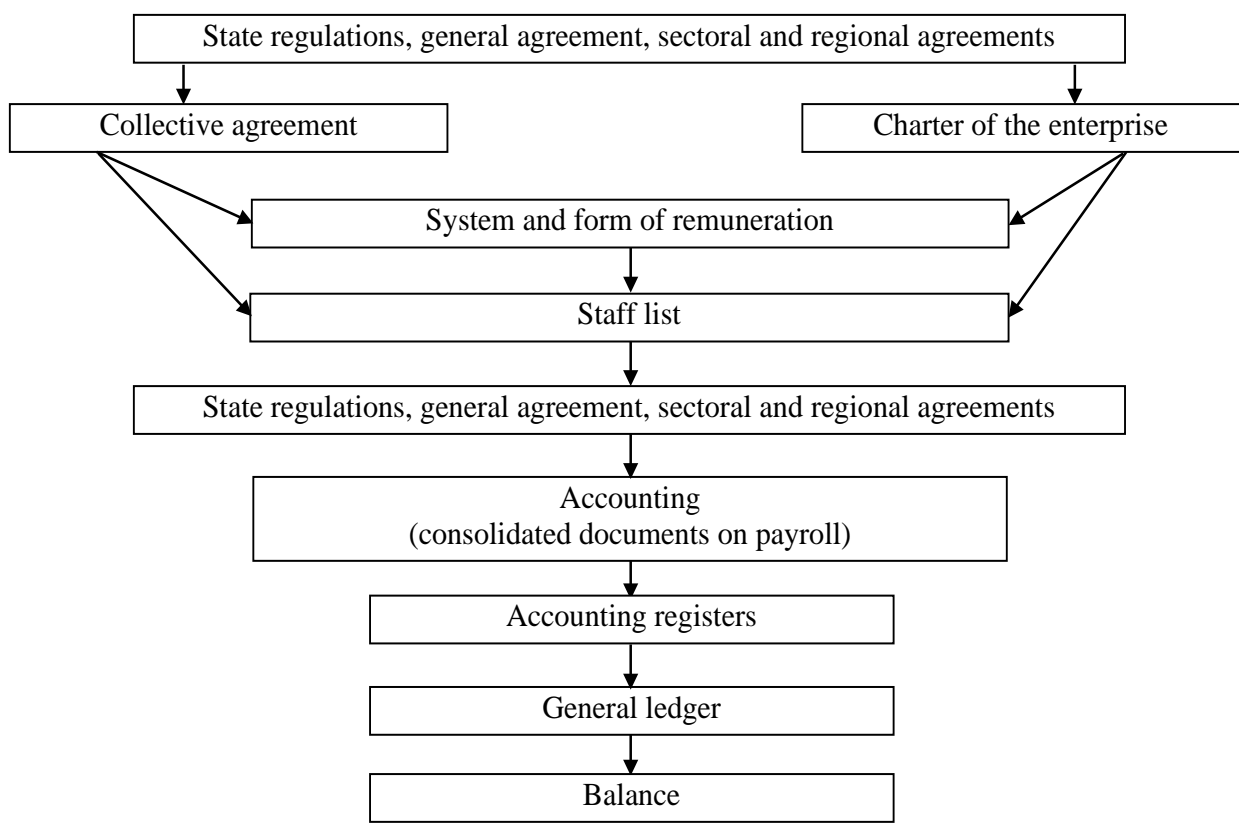

Figure 3. General scheme of the organization of accounting for payroll (compiled by the authors based on [15])

The main payments include guarantee payments. Guarantee payments are the amounts that retain the employee's salary (in whole or part) for the time when he is released from work for valid reasons provided by law and retains his job. The primary guarantee payments include payments to employees for the performance of state or public duties; payments when moving to work in another area; payments for business trips; payments for in-service training; payments for the time spent in a medical institution for examination; payments to donors; payments to employees-authors of inventions, utility models, industrial designs and innovation proposals; payments for participation in collective bargaining and preparation of a draft collective agreement or arrangement; payments to independent mediators, members of conciliation commissions and labour arbitrations while working in conciliation bodies, i.e. for participation in resolving a collective labour dispute. Guarantee surcharges are paid to the employee in case of reduced earnings. The main types of guarantee surcharges include:

- $\quad$ surcharges for minors;

- $\quad$ surcharges when transferring an employee to another job and when moving and in other cases.

Compensation benefits are amounts paid to employees in excess of their remuneration to compensate them for the costs associated with the performance of their duties and the costs associated with moving to another place of employment. They are not included in the salary.

Other incentives and compensatory payments are payments in the form of remuneration based on the results of work for the year, bonuses under special systems and regulations, compensation and other payments that are not provided by current legislation or which are made in excess of these norms.
Following ARS 26, payments for unworked time that are not subject to accumulation are non-accrued benefits that are not eligible for future periods [13]. These include the payment of annual leave and study leave, additional leave for employees who have children, payment of the first five days of temporary disability benefits, and actually unworked time by Art. 51 of the Labour Code (payments to employees engaged in part-time work). Dismissal benefits are payments to an employee that is payable by the company's decision to dismiss the employee until he reaches retirement age or by the decision of the employee to dismiss at his request until he reaches retirement age.

When dismissing employees on the initiative of the owner or his authorized body within three months, due to changes in the organization of production and labour, in addition to severance pay, such employees are paid the average salary for the period of employment, but not more than three months from the date release. The average salary is paid in this case, taking into account the amount of severance pay (Article 49-3 of the Labour Code). If such a dismissed employee got a job earlier, before the expiration of three months, these amounts' payment is suspended.

Post-employment benefits are payments to an employee (other than redundancies and equity payments of an enterprise) that are payable at the end of an employee's employment.

We are talking about pensions (pensions) and other benefits at the end of employment (life insurance, medical care). All employee benefit plans are divided into defined contribution and defined benefit plans upon the termination of employment. A defined contribution plan is when an enterprise that employs an employee determines, 
following a statutory or otherwise established formula, the number of payments to the fund and the end of its obligations to both the fund and the employee. A defined benefit plan is any other program other than a defined contribution plan (for example, when you determine in advance the amount that an employee should receive upon retirement and, based on that, determine the number of contributions to the fund).

Payments of equity instruments of the enterprise payments to the employee for which he is entitled to receive financial instruments of equity issued by the enterprise (or its parent company), or the amount of liabilities of the enterprise to the employee depends on the future price of financial instruments of equity issued by the enterprise, stock options and other equity instruments issued to employees at a cost below the fair value at which those instruments would be issued to a third party; cash payments that will depend on the future market price of the entity's shares). Agreements under which an enterprise makes payments to employees of an enterprise using equity instruments are called payment programs. Such payments are made at enterprises owned by employees and holding shares in the assets of the enterprise.

Other long-term employee benefits are employee benefits (other than post-employment benefits, redundancy payments and equity payments) that are not payable in full within twelve months after the end of the month in which the employee performed the work.

Thus, payments to employees are all forms of compensation provided by an entity in exchange for employees' services. ARS 26 sets out five types of benefits: current employee benefits, redundancy benefits, post-employment benefits, equity payments, and other long-term benefits. The share of current payments at enterprises of any form of ownership is the largest.

An important issue is the study of accounting and audit of settlements with workers.

\subsection{Accounting of Payments to Employees}

To summarize the information on settlements with the payroll staff, the Chart of Accounts provides for a passive balance sheet account 66 "Settlements for payments to employees", which according to Instruction № 291 has the following sub-accounts (Fig. 4).

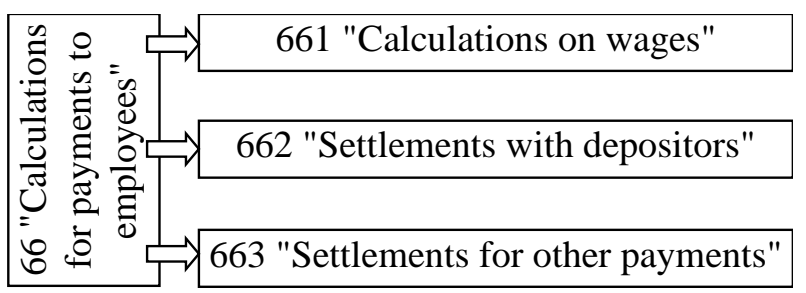

Figure 4. Detailing account 66

The first sub-account reflects the amount of accrued wages to employees who belong to the accounting and non-accounting staff.

The second - reflects the arrears of wages, which is transferred from the first sub-account, if the employee for some reason within a specified period did not receive a salary.

Credit 661 shows the amounts of accrued wages and benefits that are not included in the wage fund. Debit 661 reflects the amounts paid, including the cost of payments in kind, all types of deductions from wages, deposited amounts of unpaid wages.

The company's labour costs are one of the main elements of the enterprise's operating costs. They are associated with almost all enterprise activities, so their reflection should be guided by the provisions of the Regulations (standards) of accounting reflection should be guided by the norms of the Regulations (standards) of accounting. Consider the regular correspondence of accounts for the accrual of wages, other incentive and compensation payments (Table 1 ).

Table 1. Typical correspondence of accounts for the calculation of wages, other incentive and compensation payments

\begin{tabular}{|l|c|c|}
\hline \multicolumn{1}{|c|}{ Contents of business transactions } & \multicolumn{2}{c|}{$\begin{array}{c}\text { Corresponding } \\
\text { accounts }\end{array}$} \\
\cline { 2 - 3 } & Debit & Credit \\
\hline 1. Accrued wages for work performed on the construction and improvement of fixed assets & 15 & 66.1 \\
\hline 2. Accrued wages: & 231 \\
- $\quad$ employees of the main production & 233 \\
employees of service industries and farms & 911 \\
- $\quad$ linployees engaged in the maintenance and repair of machines and mechanisms & 66.1 \\
- $\quad$ administrative and managerial staff & 912 \\
\hline$\quad$ employees engaged in the sale of finished products & 92 \\
\hline 3. Accrued surcharges, bonuses and salaries to employees for work not related to production activities & 93 \\
\hline 4. Accrued wages to employees for work related to the liquidation and write-off of non-current assets & 949 \\
\hline 5. Accrued wages to employees engaged in labour to correct the marriage & 976 \\
\hline 6. Accrued wages to employees engaged in cargo operations and the purchase of materials and other inventory & 66.1 \\
\hline 7. Accrued wages to employees for work, the costs of which are included in the expenses of future periods & $201-209$ & 66.1 \\
\hline 8. Accrued bonuses, financial assistance, other rewards due to the created reserve for material incentives & 39 \\
\hline 9. Accrued salaries, remuneration for years of service, bonuses at the expense of targeted funding & 66.1 \\
\hline
\end{tabular}


Table 2. Typical correspondence of accounting accounts for salary deductions

\begin{tabular}{|c|c|c|}
\hline \multirow{2}{*}{ Contents of business transactions } & \multicolumn{2}{|c|}{ Corresponding accounts } \\
\hline & Debit & Credit \\
\hline 1. Withheld from the income of employees the amount of personal income tax & 661,663 & 641 \\
\hline 2. Withheld from the income of employees the amount of the single social contribution & 661,663 & 65 \\
\hline 3. Withheld from the income of employees the amount of military duty & 661,663 & 642 \\
\hline 3. Remained from the salaries of employees the balance of unused advance from the reported amounts & 661 & 372 \\
\hline 4. Carried out deductions from wages of the number of shortages and theft of property & 661 & 375 \\
\hline 5. Withheld from the salary of the loan amount provided by the company to the employee & 661 & 377 \\
\hline 6. Amounts of interest on a bank loan withheld from salary & 661 & 685 \\
\hline 7. Amounts of alimony and other payments on writs of execution withheld from employees' salaries & 661 & 685 \\
\hline 8. Trade union dues were deducted from the number of wages & 661 & 685 \\
\hline 9. Salaries, benefits, bonuses, social benefits, etc. accrued to employees paid from the pay desk & 661,663 & 301 \\
\hline 10. Listed salaries, other payments to be credited to the card accounts of employees & 661,663 & 311 \\
\hline $\begin{array}{l}\text { 11. Reflected sales to employees of the enterprise at the expense of wages of finished products, goods, } \\
\text { works and services }\end{array}$ & 661 & 701, 702, 703 \\
\hline
\end{tabular}

The debit of account 66 "Calculations for payments to employees" reflects basic and additional salaries, bonuses, temporary disability benefits, etc. As well as the cost of materials, products and goods received at the expense of wages (repayment of debts to employees for other payments); withholding of personal income tax, single social contribution, payments on organizational documents and other deductions from payments to employees (Table 2).

In the Balance Sheet (Statement of financial position) (form №1) to display information about the simple calculations of the enterprise for wages and the single social contribution are line 1155 "Other current receivables", line 1625 "Current accounts payable for insurance" and line 1630 "Current accounts payable for payroll".

In the Statement of Financial Performance (Statement of comprehensive income) (form №2), the above information is contained in Section III "Elements of operating expenses" (line 2505 "Labour costs". Line 2510 "Deductions for social activities", line 2520 "other operating costs" (in terms of labour costs and charges for social activities, which include additional operating expenses).

In the Statement of Cash Flows (by the direct method) (form №3) the expenditure of funds for wages of employees is reflected on line 3105 , the payment of a single social contribution is indicated from line C 10 "Deductions for social activities".

Accounting for the single social contribution is carried out on account 65 "Calculations for insurance". The account's credit reflects the accrual of the single social contribution, the debit - its transfer to the Pension Fund and the accrual of benefits from social insurance funds.

Per the instructions № 291 to account 65 "Insurance payments" open the following sub-accounts:

- 65.1 "According to the calculations of the compulsory state social insurance";
65.2 "On social insurance";

65.4 "On individual insurance";

65.5 "On property insurance".

In the Balance Sheet (Statement of financial position) (form №1) to display information on the state of the company's payroll and single social contribution are line 1155 "Other current receivables", line 1625 "Current accounts payable for insurance" and line 1630 "Current accounts payable for payroll".

In the Statement of financial results (Statement of comprehensive income) (form №2) the above information is contained in section III "Elements of operating expenses" (line 2505 "Labour costs", line 2510 "Deductions for social activities", line 2520 other operating expenses "(in terms of labour costs and charges for social activities, which include other operating expenses).

In the Statement of Cash Flows (by the direct method) (form №3) the expenditure of funds for the remuneration of employees is reflected on line 3105 , the payment of the single social contribution is indicated from line 3105 .

\subsection{Audit of Payments to Employees}

In a market economy, there have been significant changes in pay, which depends not only on the performance of workers but also on production units' efficiency. Every company, every industry in Ukraine, must have real and reliable information on the payroll. The audit should provide such information. Audit of employee benefits is one of the most critical and complex work areas, which requires accurate and operational data, which reflects changes in the number of employees, labour costs, categories of workers and controls the use of labour resources [3; 5].

Audit of payroll calculations is a very time-consuming and responsible task of assuring because it combines elements of financial audit and compliance audit, which is 
associated with the need to comply with labour and tax laws in the formation of financial information on payroll and other payments to employees.

The current state of development of socio-economic relations on wages makes unique demands on the formation of goals, objectives, objects of audit and evaluation of information on payments to employees, which should consider the interests of all parties to this relationship - employer, employee and state. Given these circumstances and the proven importance of the accounting and analytical category of "remuneration", it is advisable to introduce, together with the general audit of financial statements, a mandatory special task - the audit of employee benefits with the issuance of the appropriate audit opinion.

The primary purpose of auditor's pay review is to identify the strengths of the control to ensure that there are no material errors. A more detailed description of the audit of payroll calculations' main objectives is shown in Fig. 5.

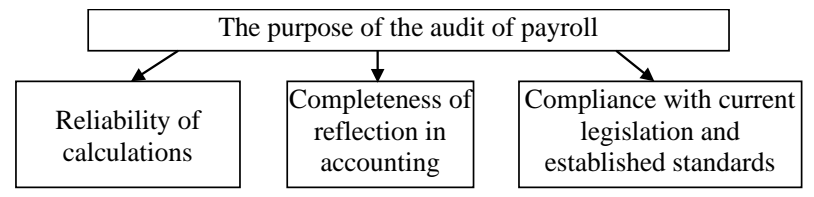

Figure 5. The purpose of the audit of payroll

The main task of the audit of wages - checking compliance with regulations when calculating wages, deductions from it and the correctness of accounting for wages.

The most important tasks of the audit of payments to employees include:

- checking the accounting of personnel of employees of the enterprise;

- checking the correctness of the calculation of basic, additional wages and other incentive and compensation payments;

- checking the correctness of the documentation of payroll calculations;

- checking the correctness of the analysis of the average wage;

- verification of the validity of the allocation of labour costs to the cost of production or operating costs that are not included in the cost of goods sold;

- study of the correctness of the distribution of labour costs between the types of finished products (work performed, services rendered) and by reporting periods;

- checking the timeliness of payments to employees for payments;

- checking the correctness of accruals to the payroll and deductions from wages, the timeliness of their payment to the relevant authorities;

- checking the status of accounting for employee benefits; checking the timeliness of payment of wages [2; 3 ; $6]$.

In the course of carrying out the audit, it is possible to use various methods and methodical receptions: recalculation, an estimation of actual presence, comparison. Thus, to verify the calculation of wages used methods of comparing accounting data with primary documents (salaries approved in the staffing, and actual accruals, timesheets and payroll), recalculations (the auditor lists the amounts that were withheld, and compares with norms of current legislation), etc. There are also specific ways to verify documents. For example, primary documents that are the basis for accrual and payment of wages (spreadsheets, settlement and payment information) are studied in combination, ie in a continuous and selective manner (if the auditor checked a number of similar primary documents and found errors, then he can assume that the document from this pack is error-free.

The visual display of information sources of audit of operations on payments to employees is shown in Fig. 6.

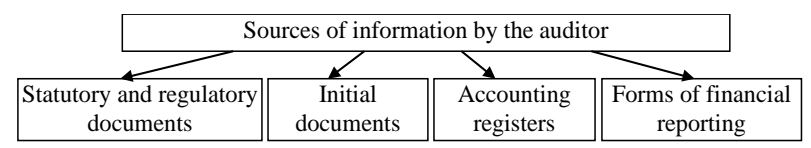

Figure 6. Sources of information on the audit of employee benefits

Employees of this enterprise or representatives of other organizations can be involved to conduct the inspection. Each of these approaches has its advantages and disadvantages. Their employees know more about the organization. It is easier for them to determine which aspects need to be evaluated. It is easier for them to conduct surveys and questionnaires because auditors less see them as a threat, i.e. something hostile. However, it is more difficult for them to look at the problems "from the outside", they are largely accustomed to the existing order. Therefore, it is difficult for them to be completely objective in their assessments. Such qualities as objectivity and independence, which are more characteristic of external auditors, who do not need to care about the "honour of the firm", they do not depend on the leaders of the enterprise and who, finally, as specialists in labour and its payment, are aware of the latest ideas and achievements. This is appropriate because the organization of work is closely related to labour law. The assessment of the legitimacy of the firm is one of the audit's objectives.

\section{Results}

As shown by the theoretical and methodological analysis of literature sources, accounting and audit of settlements with employees can be improved. 


\subsection{Improving Accounting for Payments to Employees}

Accounting Regulation (Standard) 26 "Settlements with Employees" provides for the distribution of payments for current payments, dismissal payments, post-employment payments, payments in equity instruments, and other long-term payments. Current payments to employees include wages for salaries and tariffs, other accruals for wages; payments for overtime (annual leave and other paid overtime); bonuses and other incentive payments payable within twelve months after the end of the period in which the employees perform the relevant work, etc. Thus, in our opinion, it is necessary to make changes to the Chart of Accounts. Based on the fact that through account 66 "Calculations of employee benefits" payments are made amounts that can not be clearly identified with wages, so it is necessary to open sub-accounts with a more detailed structure, which are presented in Fig. 7.

This proposal will lead to a quick search for the necessary information on the calculations with each employee of the company, which will reduce the time spent by the accountant.

\subsection{Improving the Audit of Settlements with Employees}

To prevent errors in the account is necessary to conduct an audit promptly. To do this is essential to develop a methodology for auditing payments to employees.

The purpose of the audit of settlements with employees is to establish compliance with the methodology used in the organization of accounting for payroll transactions to identify errors or violations, the degree of their impact on the reliability of financial statements to verify the accuracy and correctness of accounting settlements with employees.

Tasks of settlements with employees: verification of compliance with the provisions of labour legislation related to the calculation of wages, the availability and compliance with the legislation of the primary documents on the accounting of working time; verification of accounting and accrual of wages, other types of payments related to the payroll; checking the correctness of the calculation of annual leave.

When conducting an audit of the accrual of benefits to employees, it is necessary to identify compliance with the procedure for accounting for settlements with employees with the requirements of legislation and applicable regulations. The plan of the audit of settlements with employees is a document of organizational and methodological nature and consists of a list of works at the main stages of the audit and deadlines for their implementation, indicating the sources of information. To do this, a general plan for the audit of settlements with employees, which is shown in Fig. 8.

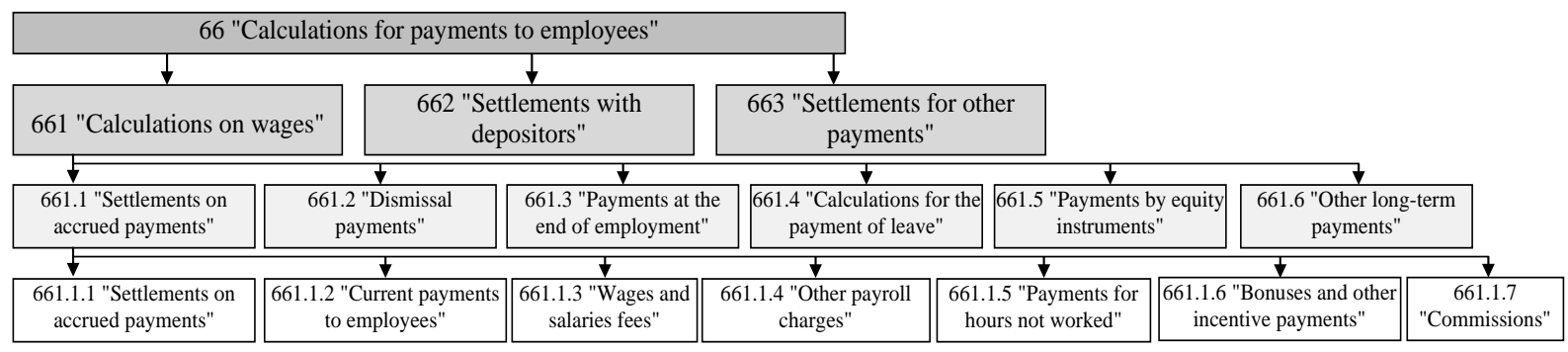

Figure 7. The detailed structure of account 66 "Calculations for employee benefits"
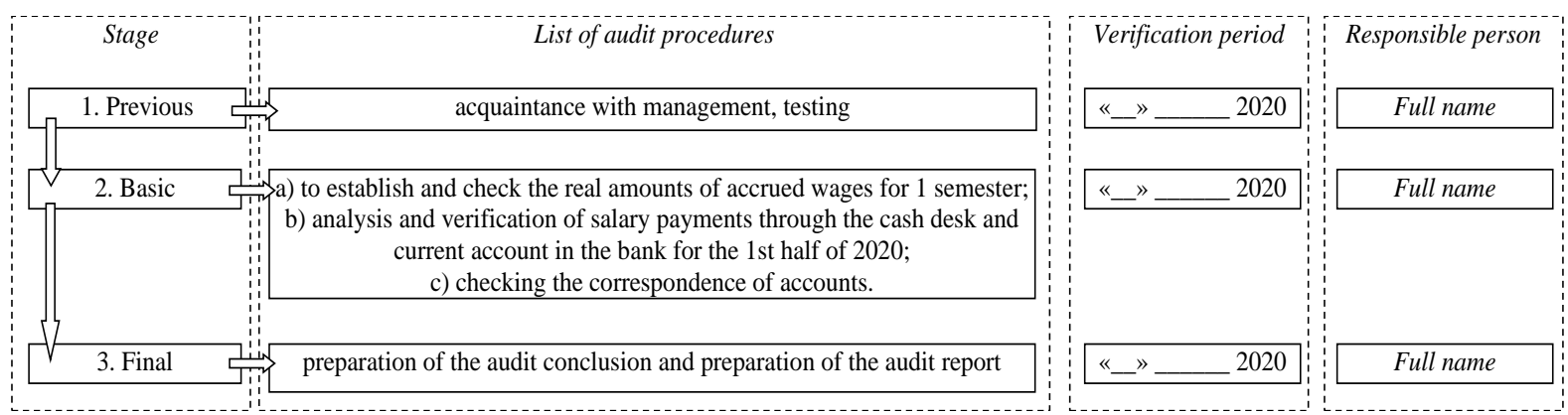

Figure 8. The general plan for audit of payments to employees 
The employee audit program is a detailed list of audit procedures indicating the purpose of the audit, audit evidence, audit methods, the index of the auditor's working papers, and the performers required for the audit (Table 3).

To solve the tasks of the audit of settlements with employees, we offer working documents of the auditor (Table 4-6), which in the opinion of the authors will be substantiated evidence of quality audit of wage calculations.

The proposed recommendations can help the organization to streamline and improve the accounting and audit of payments to employees, save the company financial resources and time of employees and help avoid penalties during the inspection.

Table 3. The program of carrying out the audit of payments to employees

\begin{tabular}{|c|c|c|c|c|c|}
\hline Audit procedures & The purpose of the audit & Audit evidence & $\begin{array}{c}\text { Verification } \\
\text { method }\end{array}$ & $\begin{array}{c}\text { Responsible } \\
\text { person }\end{array}$ & Notes \\
\hline $\begin{array}{l}\text { 1. Existence of a collective agreement, } \\
\text { provisions on remuneration, provisions on } \\
\text { bonuses, as well as: availability of orders } \\
\text { on admission and dismissal; availability of } \\
\text { timesheets; availability of staff list }\end{array}$ & Check documents & $\begin{array}{l}\text { Contracts, } \\
\text { regulations, } \\
\text { primary } \\
\text { documentation }\end{array}$ & $\begin{array}{l}\text { Documentary } \\
\text { inspection, } \\
\text { reconciliation }\end{array}$ & & \\
\hline $\begin{array}{l}\text { 2. Checking the compliance of surnames } \\
\text { and amounts in the settlement and } \\
\text { payment statements }\end{array}$ & $\begin{array}{l}\text { Check the availability and } \\
\text { correctness of the primary } \\
\text { documents }\end{array}$ & $\begin{array}{l}\text { Settlement and } \\
\text { payment } \\
\text { information, staff } \\
\text { list }\end{array}$ & $\begin{array}{l}\text { Documentary } \\
\text { inspection, } \\
\text { reconciliation }\end{array}$ & & \\
\hline $\begin{array}{l}\text { 3. Checking the correctness of the } \\
\text { calculation of wages for salaries when } \\
\text { working for less than a month }\end{array}$ & \multirow{4}{*}{$\begin{array}{l}\text { Verification of the amount } \\
\text { and availability of } \\
\text { documents for the payment } \\
\text { of wages, the reality of } \\
\text { wage transactions, the } \\
\text { correctness of the } \\
\text { calculation of wages and } \\
\text { other payments, the } \\
\text { validity of the } \\
\text { completeness of the } \\
\text { reflection }\end{array}$} & $\begin{array}{c}\text { Primary } \\
\text { documentation, } \\
\text { timesheets } \\
\end{array}$ & Selective & & \\
\hline $\begin{array}{l}\text { 4. Checking the correctness of the } \\
\text { calculation of wages for vacation }\end{array}$ & & Timesheets & $\begin{array}{l}\text { Documentary } \\
\text { verification, } \\
\text { selective }\end{array}$ & & \\
\hline $\begin{array}{l}\text { 5. Make sure that the accrued and paid } \\
\text { amounts of wages are correct }\end{array}$ & & $\begin{array}{l}\text { Description, } \\
\text { goals, objectives } \\
\text { of the standard. }\end{array}$ & $\begin{array}{l}\text { Documentary } \\
\text { check, } \\
\text { calculation }\end{array}$ & & \\
\hline $\begin{array}{l}\text { 6. Checking wage payments to bank } \\
\text { accounts }\end{array}$ & & $\begin{array}{l}\text { Payment details, } \\
\text { payment orders }\end{array}$ & $\begin{array}{l}\text { Documentary } \\
\text { inspection, } \\
\text { continuous }\end{array}$ & & \\
\hline
\end{tabular}

Table 4. Auditor's working document to verify the compliance of names and amounts in the settlement and payment statements

\begin{tabular}{|c|c|c|c|c|c|c|}
\hline \multirow[b]{2}{*}{ Date } & \multirow[b]{2}{*}{ Full Name } & \multirow[b]{2}{*}{ According to management } & \multicolumn{3}{|c|}{ According to the inspection } & \multirow{2}{*}{$\begin{array}{c}\text { Deviation } \\
(+/-)\end{array}$} \\
\hline & & & $\begin{array}{l}\begin{array}{l}\text { Accrued } \\
\text { together }\end{array} \\
\end{array}$ & Withheld & $\begin{array}{c}\text { Total for } \\
\text { issuance, UAH }\end{array}$ & \\
\hline 1 & 2 & 3 & 4 & 5 & 6 & 7 \\
\hline & & & & & & \\
\hline & & & & & & \\
\hline
\end{tabular}

Table 5. Working document to verify the correctness of the calculation of wages for vacation

\begin{tabular}{|c|c|c|c|c|c|c|c|}
\hline \multirow{2}{*}{ Full Name } & \multirow{2}{*}{$\begin{array}{c}\text { According to } \\
\text { management }\end{array}$} & \multicolumn{7}{|c|}{$\begin{array}{c}\text { According to the inspection } \\
\text { calculate }\end{array}$} & Days & $\begin{array}{c}\text { Adjustment } \\
\text { factor }\end{array}$ & $\begin{array}{c}\text { Average earnings } \\
\text { per 1 cal. day }\end{array}$ & $\begin{array}{c}\text { Amount, } \\
\text { UAH }\end{array}$ & $\begin{array}{c}\text { Deviation } \\
\text { (+/-) }\end{array}$ \\
\hline 1 & 2 & 3 & 4 & 5 & 6 & 7 & 8 \\
\hline & & & & & & & \\
\hline
\end{tabular}

Table 6. Working document in the correctness of accrued and paid amounts of wages

\begin{tabular}{|c|c|c|c|c|c|c|c|c|c|c|}
\hline \multirow{2}{*}{$\begin{array}{c}\text { Full } \\
\text { Name }\end{array}$} & \multirow{2}{*}{$\begin{array}{c}\text { According to } \\
\text { management }\end{array}$} & salary & rank & service & $\begin{array}{c}\text { intensity } \\
\text { allowance }\end{array}$ & premium & $\begin{array}{c}\text { According to the inspection } \\
\text { aid }\end{array}$ & $\begin{array}{c}\text { hospital } \\
\text { accrued, } \\
\text { UAH }\end{array}$ & $\begin{array}{c}\text { Deviation } \\
\text { (+/-) }\end{array}$ \\
\hline 1 & 2 & 3 & 4 & 5 & 6 & 7 & 8 & 9 & 10 & 11 \\
\hline & & & & & & & & & & \\
\hline & & & & & & & & & & \\
\hline
\end{tabular}




\section{Conclusions}

Wages, the level of payments to employees, their nature and structure are of great social importance and affect the standard of living and the current and future performance of the enterprise. In addition, the organisation's effectiveness depends on the work of employees themselves, and their motivation, in turn, depends on the level of wages and working conditions. Therefore, the chosen topic is quite relevant, and the proposed recommendations can help organizations streamline and improve accounting and audit of payments to employees, save the company financial resources and time of employees and help avoid penalties for inspections; besides, the work of employees will be much easier and faster. This creates all the conditions for more efficient accounting, which helps to increase the company's profits in the future.

\section{REFERENCES}

[1] L. Ocheretko, I. Khokhlova A. Problems of accounting and taxation of payments for employee payments and ways to solve them, DOI: 10.32702/2307-2105-2018.10.65, 2018.

[2] Y. Yiannoulis. Literature Review on the Hellenic Auditing and Accounting Environment before, during and after the Crisis Period, Universal Journal of Accounting and Finance, 7(2), pp. 43-49, 2019. DOI: 10.13189/ujaf.2019.070202

[3] H. Tarasova, V. Misyachnuy. Organizational and methodological aspects of analysis of calculations on payments to employees, DOI: 10.25313/2520-2057-2019-44781, 2019.

[4] J. Miraj, Zh. Wang. Analysis of Accounting Reforms in the Public Sector of Pakistan and Adoption of Cash Basis IPSAS, Universal Journal of Accounting and Finance, Vol. 6, No. 2, pp. 47-53, 2018. DOI: 10.13189/ujaf.2018.060203.
[5] L. Ivanchenkova et al. Improving accounting and analysis of innovative costs, International Journal of Innovative Technology and Exploring Engineering, 2019, 9(1), pp. 4003-4009

[6] T. Melikhova, A. Lukashova. Improvement of the methodology of accounts internal audit with accountable persons for improving the economic security of the enterprise, Efektyvna ekonomika, 2019, DOI: 10.32702/2307-2105-2019.1.30

[7] S. Kafka et al. Management and control model of organizational change in the process of monitoring of financial results, International Journal of Recent Technology and Engineering, 2019, 8(3), 7261-7265.

[8] K.O. Deyganto. Factors Influencing Taxpayers' Voluntary Compliance Attitude with Tax System: Evidence from Gedeo Zone of Southern Ethiopia, Universal Journal of Accounting and Finance, 2018, Vol 6 No 3, 92-107.

[9] J. Miraj, Zh. Wang Zhuquan. Analysis of Accounting Reforms in the Public Sector of Pakistan and Adoption of Cash Basis IPSAS, Universal Journal of Accounting and Finance, 2018, Vol 6 No 2, 47-53.

[10] A. Makarenko, K. Katsay. Improvement of the audit of payment at the enterprise, Ekonomika ta derzhava, DOI: 10.32702/2306-6806.2020.1.40

[11] O. H. Chepets, I. Y. Kinebas. The Ways to Improve Accounting and Auditing of Labour Payment Calculations, Business Inform, 2019, 7(498), 225-230.

[12] International Accounting Standard 19 "Employee Benefits", Online available from http://zakon.rada.gov.ua/laws/show/9 29011

[13] Regulation (Standard) of Accounting 26 "Payments to employees", Online available from https://zakon.rada.gov.u a/laws/show/z1025-03\#Text

[14] State Statistics Service of Ukraine, Online available from www.ukrstat.gov.ua

[15] F. Butynets, A. Gerasimovych, G. Kireitsev. Accounting and financial accounting, Ruta Zhytomyr, 2003. 